\title{
Infância e educação infantil: Uma abordagem histórica
}

\author{
Magali dos Reis
}

Escrever sobre a obra Infância e educação infantil: Uma abordagem histórica é uma aventura desafiadora, mas que ao mesmo tempo estimula e excita a imaginação. O autor, Moysés Kuhlmann Júnior, dispensa apresentações, mas é importante destacar que ele é um pedagogo dedicado à pesquisa historiográfica na área de educação infantil.

A obra está dividida em oito capítulos que circunscrevem grande parte da trajetória acadêmica do autor e constitui-se num minucioso estudo sobre educação infantil, abordando temas ligados à assistência e às políticas para os pequenos, entre outros.

Já na introdução, Kuhlmann Jr. traz um importante apanhado sobre as pesquisas mais recentes na área de educação infantil, analisando mais de dez obras sobre o tema. Dando ênfase à importância da história para a formação do profissional de educação, o autor destaca a dinâmica dessa "ciência", avaliando que é a sólida formação teórica que permitirá ao profissional trazer das abstrações um alimento para a prática cotidiana, com base na reflexão e no pensamento crítico (p. 6). Para o autor, a história é dinâmica, exigindo pesquisas sistemáticas, crítica às fontes de investigação, e ainda demanda procedimentos próprios.

No primeiro capítulo, "Infância, história e educação", o autor traz um importante levantamento da bibliografia sobre o tema, ampliando as análises para além das exaustivas referências à obra de Philippe Ariès,

\footnotetext{
* Moysés Kuhlmann Jr., Infância e educação infantil: Uma abordagem histórica. Porto Alegre: Mediação, 1998, 209 p.

** Docente do Curso de Pedagogia da PUC-MG, campus de Poços de Caldas. Mestre em Educação pela Faculdade de Educação - Unicamp. E-mail: mreis@obelix.unicamp.br
} 
fato que torna o capítulo mais instigante no que diz respeito à história da infância, avançando na discussão sobre o tema.

No segundo capítulo "Assistência e Pan Americanismo: O Dia da Criança e a comemoração da descoberta da América", as análises giram em torno das políticas diplomáticas, situando a infância no contexto das relações internacionais no continente americano.

"A proteção à infância e a assistência científica" são temas abordados no terceiro capítulo. A assistência científica é um termo cunhado pelo autor em sua dissertação de mestrado defendida em 1990, e pretende caracterizar as políticas de assistência gestadas na virada do século XIX para o século XX.

A história das instituições de educação infantil recebe especial destaque nos dois capítulos seguintes. "As exposições internacionais e a difusão das creches e jardins-de-infância (1867-1922)" é o tema do quarto capítulo do livro e versa sobre a educação e a educação infantil no plano internacional. Nesse estudo foram utilizadas fontes documentais referentes às exposições internacionais ocorridas em diversos países no final do século passado e início deste século.

No quinto capítulo "Instituições pré-escolares assistencialistas no Brasil (1899-1922)", o autor analisa a história das instituições pré-escolares - creches, escolas maternais e jardins-de-infância - em nosso país, ressaltando a assistência à infância que, segundo o autor, congrega e articula interesses jurídicos, empresariais, políticos, médicos, pedagógicos e religiosos em torno de três influências básicas: a jurídico-policial, a médico-higienista e a religiosa (p. 82).

Quanto às concepções pedagógicas expressas nas instituições de educação infantil, dois capítulos trazem importantes reflexões - "Pedagogia e rotinas no jardim-de-infância" (sexto capítulo) escrito em co-autoria com Maria Carmen Barbosa (UFRGS), que aborda tanto a difusão dos jardinsde-infância quanto as atividades e propostas para o jardim-de-infância Caetano de Campos (SP), trazendo importantes reflexões sobre a rotina naquela instituição. Já o capítulo seguinte, "A educação assistencialista", contrariando as análises que vinham se consolidando desde a década de 1970, de que não havia uma proposta educativa para as crianças de camadas mais pobres da sociedade em instituições de convívio coletivo, o autor mostra que havia, sim, a proposta de uma pedagogia da submissão objetivando disciplinar e apaziguar as relações sociais (p. 181). 
Para finalizar, o oitavo capítulo, "Políticas para a educação infantil: Uma abordagem histórica", analisa historicamente a constituição e a difusão de instituições de educação infantil, trazendo elementos para reflexões acerca das recentes políticas públicas de educação e ainda contribui para a discussão dessas políticas e das práticas atuais.

O conjunto? Um livro denso que prima pelo rigor acadêmico, que utiliza fontes ainda pouco exploradas na história da educação, mas nem por isso a leitura torna-se monótona; ao contrário, cada capítulo incita a leitura de outro. Além disso, contribui para as discussões recentes sobre a história da educação infantil, e para a compreensão da infância como categoria histórica.

A obra interessa a todos aqueles que são sensíveis à infância e à educação de crianças pequenas, seja profissional que atua diretamente com a criança, seja pesquisador que tenha interesse pela temática.

Não deixe de ler!!! 